\title{
TITLE INDEX OF VOLUME 17
}

\section{EDITORIALS}

$1,49,101,177,221$

\section{UNITED NATIONS ACTIVITIES}

UN/GA

- Resolution of Forty-First Session

- WCED: Report Before Assembly

UN/ECE

- Transboundary Air Pollution

- Senior Advisers: Fifteenth Session

- 30\% Protocol in Force

- Nitrogen Oxides

- Abatement of NOx Emissions

UNEP

- Environmental Impact Assessment: Principles

Developed (John E. Bonine)

- Guidelines for Diesel Vehicles

-CFCs: Preparation of Protocol

- CFCs: No Agreement on Protocol

- Preparation for the Fourteenth Session

- Chemicals in International Trade

-14th Governing Council

- Ozone Protocol Adopted

IAEA

- General Conference

CSCE

- Vienna Meeting 1986: Follow-up to the Conference

UNCTAD/VII

- WCED and Developing Countries

AMCEN II

- African Ministers Meet

OTHER INTERNATIONAL DEVELOPMENTS

The Three System and Mankind (M. Kassas)

Réflexions critiques sur le droit international de l'environnement (Michael Bothe)

MARPOL - Annex II in Force

Wetlands - Legal Problems

Economic Summit Conference

UNEP/IPU

- Inter-Partliamentary Conference on Environment: Progress Review

- Inter-Parliamentary Conference: Progress Surveyed

ICC

- Environmental Guidelines for World Industry

- Position of Industry on WCED Report

L'importance Croissante des Risques Industriels (Henri Smets)

A Matter of Degrees: Energy Policy and the WWF Greenhouse Effect (Irving M. Mintzer)

- Conservation and Religion

OECD

- High Level Meeting of Chemicals Group

Religion and Nature

Elizabeth Haub Price

Ramsar Convention

- Progress Achieved

CITES

- Conference of the Parties

\section{REGIONAL AFFAIRS}

Gt. Britain, Fedral Republic of Germany, Switzerland, Austria and the Socialist Countries - Air Purification Policy -

(Richard Brabazon Macrory, Zdenek Madar and Karl Christian Onz)
EC

- Fourth Environmental Action Programme

- Environment: Proposal for Financial Support

- Community Up-date (Malcolm J. Forster)

- Community Up-date (Malcolm J. Forster)

EP

Proposals for Resolutions on

- Environmental Impact Studies

- Environment and Employment Creation

- Antarctica

- Community Nature Reserves

- East African Region

- Policy and Action Programme

South Pacific Region

- Protection of Natural Resources 70

- Protocols adopted

Council of Europe

- Texts adopted

Canada/USA

Caribou Conservation Agreement

Nordic Countries

Sustainable Development - How?

Caribbean Region

Declaration on Environment

\section{NATIONAL AFFAIRS}

USA/Mexico

- Co-operation on Shipments of Hazardous Wastes

- Joint Wildlife Conservation Programmes

\section{China/USA}

- Co-operation in Nature Conservation

Norway/Sweden

- Nuclear Facilities Agreement

Nigeria

- Policy Making and Implementation: Environmental Sanitation in Oyo State

(Afolabi A. Adedibu)

New Zealand

- New Environmental Administration (T.W. Fookes)

Portugal

- New Law

USA

- Arctic National Wildlife Refuge: Oil and Gas Potential

- Oil Spill Liability and Compensation Protocols

- Mineral Rights in Wilderness Areas - Just Compensation Feasible?

(Nancy Cruickshank and David A. Gulley)

Germany, Federal Republic

- Presentation of WCED Report

\section{SELECTED DOCUMENTS}

\section{UN/GA}

- Resolutions Adopted by the Forty-First Session:

Report of the International Law Commission

- Financial Reports and Audited Financial Statements and Reports of the Board of Auditors

- Chemical and Bacteriological Weapons (2nd Review Conference)

- Prohibition of Chemical and Bacteriological Weapons (Parts B, C and D)

- Human Rights and Use of Scientific and Technological Developments

- Election of Nineteen Members of the Governing Council of UNEP

- Election of Members of the International Law Commission 
- Report of the International Atomic Energy Agency

- Law of the Sea

- Question of Antarctica (Parts A, B and C)

- New and Renewable Sources of Energy

- International Co-operation in the Peaceful Uses of Outer Space

- Co-operation between the United Nations and the Organization for African Unity

\section{UNEP}

- CFCs: Draft Protocol

- Principles of Environmental Impact Assessment

- Draft Protocol on Chlorofluorocarbons

- Chemicals in International Trade: Guidelines for the Exchange of Information

- 14th Governing Council - Decision and Recommendations

- African Ministerial Conference on the Environment

- First Arab Ministerial Conference on Environmental Considerations in Development

- The Action Plan for the Environmentally Sound Management of the Common Zambezi River System

- Transfer of Environmental Protection Technology

- The Clearing-House Mechanism

- Implementation of the Recommendations of the 1984 Inter-Parliamentary Conference on Environment

- Co-operation between UNEP and CIDIE

- The Environment Fund

- Periodicity and Duration of Governing Council Sessions

- Biennial Cycle of Sessions - Draft Resolution for the Consideration of the General Assembly

- Amendments to the Rules of Procedure of the Governing Council

- Amendments to the Conditions for the Estimations of Future Resources and their Apportionment

- Amendment to the Financial Rules of the Fund of the United Nations Environment Programme

- World Environment Day 1987

- Co-operation with Non-Governmental Organizations

- Rationalization of Documentation

- Programme Policy and Implementation

- Improvement and Harmonization of Environmental Measurement

- Environmental Impact Assessment

- Biological Diversity

- Safe Management of Chemicals

- Protection of the Ozone Layer

- International Register of Potentially

Toxic Chemicals

- International Convention and Protocols in the Field of the Environment

- List of Selected Environmentally Harmful Chemical Substances

- Environmentally Sound Management of Hazardous Wastes 157

- Shared Natural Resources and Legal Aspects of Offshore Mining and Drilling

- Regional and Sub-Regional Programmes in Latin America and the Caribbean

- Global Climate Change

- Implementation of the Plan of Action to Combat Desertification

- The State of the World Environment 1987

- Emerging Environmental Issues

- Report of the World Commission on Environment and Development

- WCED Report: GC Draft Resolution for UN/GA

- The Environmental Perspective to the Year 2000 and Beyond

- Draft Resolution for Submission by the Governing Council to the General Assemlby

Environmental Prspective to the Year 2000 and Beyond
AMCEN II

- African Ministerial Conference on the Environment: Extracts from Decisions

- Organizational and Institutional Matters

- Regional Technical Co-operation Network on Environment and Development

- Operational Arrangements for the Four Committees of the Conference

- Priority Subregional Activities

- Village and Stock-raising Pilot Projects

- Inter-Agency Working Group

- Inter-Agency Working Group

- Environmental Education and Training Council of UNEP at its Fourteenth Session

\section{Group of Seven}

- Economic Summit: Thirteenth International Session

Council of Europe

- The Consequences of Current Soil Degradation

- Pollution of the Rhine

- Biogenetic Revolution in Agriculture

- Montreal Protocol on Substances that Deplete the Ozone Layer

IAEA

- Measures to Strengthen International Co-operation in Nuclear Safety and Radiological Protection

- General Conference Special Session: Final Document

USA/Mexico

- Transboundary Shipments of Hazardous Wastes and Hazardous Substances

Norway/Sweden

- Agreement on Exchange of Information and Early Notification Relating to Nuclear Facilities

EC

- Policy and Action Programme of the

Environment (1987-1992)

- Fourth Environmental Action Programme:

Action at International Level

- Action relating to the Environment: Financial Support WWF

- Assisi: Muslim Declaration on Nature

- Religion and Nature

- Buddhist Declaration

- Christian Declaration

- Hindu Declaration

- Jewish Declaration

CSCE

Follow-up to the Helsinki Conference: Resolutions - Proposal on the Environment

- Air Pollution

- Water Pollution

- Major Industrial Accident Hazards

- Toxic and Dangerous Waste

- Natural Resources Management and Development

- Ecological Forum of the Participating States

- Further Development

- Ozone Layer

- Further Development of Concerted Measures Against Air Pollution within the Framework of the ECE

- The Long-Term Strategy in the Participating States of the CSCE

- Air Pollution and the Decay of Forests

\section{IPU/UNEP}

- Parliamentary Measures: Findings and Conclusions

- Summary of Special Statements made by Prof. Kassas and Dr. Holdgate

\section{WHO/UNEP}

- Environment and Health: Recommendations for Action 
South Pacific

- Convention for the Protection of the Natural

Resources of the South Pacific Region

- Protocol for the Prevention of Pollution of

the Region by Dumping

- Protocol Concerning Co-operation in Combating

Pollution Emergencies in the Region

Ramsar Convention

- Recommendations of Third Meeting of the Contracting Parties

CITES

Resolutions of the Sixth Meeting of the Conference of the Parties

Nordic Countries

- Conclusions: Conference on Environment and Development

\section{Caribbean}

- Declaration of First Interparliamentary Conference on the Environment in Latin America and the Caribbean

- Environment Projects and Employment Creation (Proposal)

- Community Policy and Action Programme (Motion for a Resolution)

UNCTAD VII

- WCED: Gro Harlem Brundtland's Address

UN/ECE

- Abatement of Emissions of Nitrogen Oxides: Revised Draft Protocol

ICC

\section{AUTHOR INDEX OF VOLUME 17}

John E. Bonine, 5

Malcolm J. Forster, 18, 70

Afolabi A. Adedibu, 73

M. Kassas, 119

Michael Bothe, 123

T.W.Fookes, 129

Nancy Cruickshank and David A. Gulley, 135

Richard Brabazon Macrory, Zdenek Madar and Karl Christian Onz, 182

Henri Smets, 231

Irving M. Mintzer, 247 